\title{
From Three Fishers: Statistician, Geneticist and Person to Only One Fisher: The Scientist
}

\section{Millor Fernandes DR}

Department of Animal Science, Laboratory of Animal Biotechnology, Federal University of São Carlos, campus bell Lagoon, Brazil

*Corresponding author: Millor Fernandes DR, Department of Animal Science, Laboratory of Animal Biotechnology, Federal University of Sao Carlos, Campus bell Lagoon, 18290-000, Buri, São Paulo, Brazil, Tel: 502-852-1888; E-mail: millorfernandes@gmail.com

Rec date: February 19, 2016; Acc date: February 23, 2016; Pub date: February 29, 2016

Copyright: (C) 2016 Fernandes DRM. This is an open-access article distributed under the terms of the Creative Commons Attribution License, which permits unrestricted use, distribution, and reproduction in any medium, provided the original author and source are credited.

\begin{abstract}
Sir Ronald Fisher was the most important statistician of the twentieth century. He developed several theories that revolutionized statistics and genetics. Many scientists declared him guilty of propagation of errors because their new ideas were not understood correctly. Fisher also had a polemic and controversial social position because he arduously defended eugenics and tobacco consumption. In this paper our intention is to show the three Fishers: the statistician, the geneticist and the person. Their contributions to science were results from these three Fishers who considered one only Fisher: the scientist.
\end{abstract}

Keywords: Statistics; Genomics; Genetics; Analysis of variance; Molecular biology

\section{Introduction}

After 50 years Ronald Aylmer Fisher's death (1890-1962), he continues being one of the most important statistician of the twentieth century [1]. Some authors described him like: "I occasionally meet geneticists who ask me whether it is true that the great geneticist R. A. Fisher was also an important statistician [2] "the greatest of Darwin's successors" [3], "Fisher was a genius who almost single-handedly, created the foundations for modern statistical science..." [4]. He was called affectionately by Ron or Ronnie and he was born on February 17th, 1890, in London. He was the fourth son of George and Katie Fisher. During his childhood, he presented symptom of hypermetropy that developed his great ability with geometrical images in his mind.

Since the first years of school, he was a bright student. However, an eminent financial crisis is coming soon because his father lost all fortune in transactions with high risks. Fisher would have a little possibility to study in good schools. Then, in 1909, he was prized with a scholarship to study mathematics and astronomy at the Caius and Goinville College, Cambridge. “... I recall too the dark December evening when you [Fisher] brought the telegram from Caius to say you had won an $£ 80$ Scholarship. More than honor, this scholarship was a necessity." (Mayo, Fisher's tutor in Harrow, regarding scholarship for Caius)

He graduated in 1913, but with a great interesting in biology, too. "Fisher did not follow study in biology because he was completely astonished on complex taxonomic classification of the vertebrates' bone structure [5]."

Two persons were very important in his life: Geraldine Heath nicknamed "Gruduna", who presented her sister Ruth Eileen Gratton Guinness. Fisher was falling in love for Ruth and they get married in 26th April 1917 and had two sons and six daughters.
"His large family, in particular, reared in conditions of great financial stringency, was a personal expression of his genetic and evolutionary convictions."

Leonardo Darwin was his greater professional instigator and he helped him financially.

"He [Fisher] honored Leonardo Darwin as a father along of 30 years of friendship [6]."

Fisher isolated in himself alienated environment between 1913 and 1919. He described years later: “...an egregious failure in two occupations.", regarding to his triumphant period in Harrow and Caius, but that had not been reverted in a job associated with statistics or genetics, their big passions.

But in 1919, Fisher got the statistician-in-chief position at the Rothamsted Experimental Station, where he was able to develop their ideas on eugenics and experimentation. In 1933, he replaced K. Pearson as Chair of Galton Professor of Eugenics, at the University College of London. Afterwards, in 1943, he became Chair of Arthur Balfour Professor of Genetics, at the Cambridge University. In 1959, he was invited for a position of research scientist of the Commonwealth Scientific Industrial Research Organisation, at the University of Adelaide, Australia.

Fisher published in their books and articles new statistical ideas and concepts about small samples, experimental designs (blocks, factorial), randomization, analysis of variance, studies related to distributions $t$, $\chi^{2}, \mathrm{~N}, \mathrm{z}$ and $\mathrm{F}$, maximum likelihood, test of significance, multivariate analysis, multiple regressions, and others. In his first contribution, he published on an absolute criterion for fitting frequency curves [7], where purposed the maximum likelihood as a method to fit frequency curves. Another important contribution was the analysis of variance table. "...this is not a mathematics theorem, but merely a convenient way of arranging the arithmetic [8]."

These Fisher's new theories caused some divergences between him and the Pearsons (Karl, the father and Egon, the son), Jerzy Neyman and others [9]. Although, the scientific community did not accept Fisher's contributions at that time, he reinvented the statistics. Where 
until then K. Pearson's "bible" had been: "Every result must be followed by its probable error or be rejected as without value.", R. A. Fisher replaced it for: "exact probability test, where this probability must only depend on observations and not on a priori probabilities."

In 1918, he published a revolutionary article that supplied the bases on the biometric genetics, defining additive, dominance and epistasis variances: The correlation between relatives on the supposition of Mendelian inheritance [10]. Fisher concluded that the continuous variation between traits might be the result of the Mendelian inheritance.

Fisher wrote to K. Pearson in June 1916, saying: "I recently completed article on Mendelism and Biometry which probably be of interest to you. I find on analysis that the human data is as far as it goes, not inconsistent with Mendelism. But the argument is rather complex [11]."

K. Pearson's answer came in July 1916: "I am afraid I am not a believer in cumulative Mendelian factors as being the solution to the hereditary puzzle [11]."

In The Genetical Theory of Natural Selection [12], Fisher finally reconciled Mendel's and Darwin's defenders.

“...in The Genetical Theory of Natural Selection he [Fisher] brought genetics together with evolution by natural selection, rewriting Darwin's score in the symbols of [the emerging field of] population genetics [6]",

"Part of Fisher's efforts in the reconciliation of Mendelism and (biometric) Darwinism were the recognition that only superficial scientific scrutiny had been directed at Mendel's article by both its proponents and opponents [6]."

“...whose [mentioning Fisher] contributions made major strides forward and, in fact, reconciled the two opposing theories [Mendelism x Darwinism] [13].”

According to Thompson [14], Fisher's contributions to genetics are summarized along of decades: 1920s: evolutionary theory, defining neo-Darwinism, 1930s: analysis of linkage jointly with W. Bateson, R. C. Punnett, T. H. Morgan, 1940s: blood types, studying Rhesus system (Rh factor), 1950s: quantitative genetics based on experimentation in the genetic breeding with G. W. Snedecor from Iowa State College, 1960s: use of mathematics in the population genetics and evolutionary theory with S. Wright, considering Wright-Fisher's model, 1970s: analysis of complex traits in human genetics epidemiologist, 1980s: analysis of linkage and gene mapping in humans whose the basis was given by Fisher and J. B. S. Haldane and 1990s: polymorphisms and DNA sequences used in genetics epidemiologist, evolutionary biology and junctions theory. Since 2000 decade, Fisher's theories have been extending and applying to called "omics": genomics, transcriptomics, proteomics and metabolomics to understand physiological processes of species whose all or part of the genome sequence have already been finished.

Fisher did not consider himself as a statistician or as a geneticist, but only as a scientist. As a result of their revolutionary ideas, many scientists declare him guilty of propagation of errors.

In a TV broadcast, 1955, about Science and Religion, he said: “The custom of making abstract dogmatic assertions is not, certainly, derived from the teaching of Jesus, but has been a widespread weakness among religious teachers in subsequent centuries. I do not think that the word for the Christian virtue of faith should be prostituted to mean the credulous acceptance of all such piously intended assertions. Much self-deception in the young believer is needed to convince himself that he knows that of which in reality he knows himself to be ignorant. That surely is hypocrisy, against which we have been most conspicuously warned."

His devotion to scientific truth allowed him to affirm "...if a statistician was consulted only to the experiment end, he would only be able to certify its cause mortis."

He had a polemic and controversial social position because he arduously defended the eugenics. In Some hopes of a eugenist [15], Fisher proposed that families, whose parents were healthful and welladapted, received a proportional bonus on salary to stimulate them to have also a greater number of healthful and well-adapted child. This cause was defended by own Fisher in the British parliament, being rejected.

\section{Another point defended by Fisher was the tobacco consumption.}

"There seems to be some danger - I cannot assess whether it is infinitesimal or serious. This habit of mine of smoking isn't very important to me [16]."

"It has been suggested that the fact that Fisher was employed as consultant by the tobacco firms in this controversy casts doubt on the value of his arguments. This is to misjudge the man. He was not above accepting financial reward for his labours, but the reason for his interest was undoubtedly his dislike and mistrust of puritanical tendencies of all kinds; and perhaps also the personal solace he had always found in tobacco [5]." Fisher was member of several scientific societies and awarded with several honors and prizes. He died on July 29th, 1962, in Adelaide, Australia, due to a colon cancer aggravated by his smoking habit.

\section{Conclusion}

Sir Ronald Aylmer Fisher spent his life searching incessantly for the certain in the presence of the uncertain, and left a significant legacy to science that himself could never imagine. After 123 years from his born, this article was an honor to this genius of the science in the twentieth century. Certainly, their theories have been propagated for scientific community, who only years later from his die, could understand that Fisher was correct in all those he postulated.

\section{References}

1. Vyas SA, Desai SP (2015) The Professor and the Student, Sir Ronald Aylmer Fisher (1890-1962) and William Sealy Gosset (1876-1937): Careers of two giants in mathematical statistics. J Med Biogr 23: 98-107.

2. Savage LJ (1976) On rereading R. A. Fisher with discussion. Annals of Statistics 4: 441-500.

3. Dawkins R (1995) River out of Eden: a Darwinian view of life. Basic Books NY.

4. Hald A (1998) A history of mathematical statistics from 1750 to 1930 Wiley.

5. Yates F, Mather K (1963) Ronald Aylmer Fisher. Biographical Memoirs of Fellows of the Royal Society of London 9: 91-120.

6. Box JF (1978) R A Fisher: the life of a scientist. John Wiley.

7. Fisher RA (1912) On an absolute criterion for fitting frequency curves. Messenger of Mathematics 41: 155-160.

8. Fisher RA, Mackenzie WA (1923) Studies in crop variation. II. The manurial response of different potato varieties. Journal of Agricultural Science 13: 311-320. 
Citation: Fernandes DRM (2016) From Three Fishers: Statistician, Geneticist and Person to Only One Fisher: The Scientist. J Biom Biostat 7: 282. doi:10.4172/2155-6180.1000282

Page 3 of 3

9. Salsburg D (2001) The lady tasting tea: how statistics revolutionized science in the twentieth century. WH Freeman Company.

10. Fisher RA (1918) The correlation between relatives on the supposition of Mendelian inheritance. Transactions of the Royal Society of Edinburgh 52: 399-433.

11. Pearson ES (1968) Studies in the history of probability and statistics. XX Some early correspondence between W. S. Gosset, R. A. Fisher and Karl Pearson. Biometrika 55: 445-457.

12. Fisher RA (1930) The Genetical Theory of Natural Selection. Press Oxford.
13. Piegorsch WW (1990) Fisher's contributions to genetics and heredity, with special emphasis on the Gregor Mendel controversy. Biometrics 46: 915-924.

14. Thompson EA (1990) R.A. Fisher's contributions to genetical statistics. Commons below Biometrics 46: 905-914.

15. Fisher RA (1914) Some hopes of a eugenist. Eugen Rev 5: 309-315.

16. Fisher RA (1958) Cigarretes, cancer and statistics. Centennial Review 2: 151-166. 